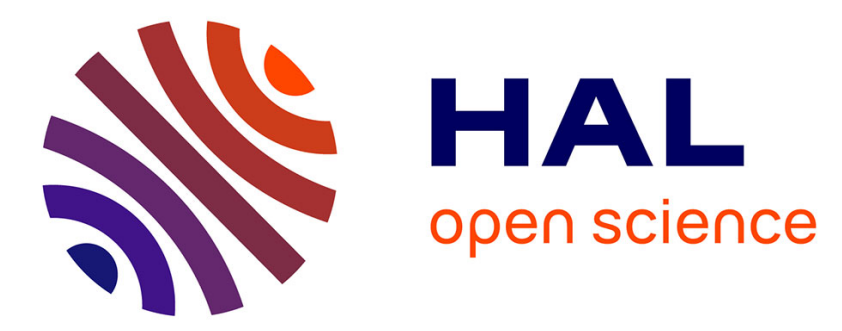

\title{
A new Cocconeis (Bacillariophyceae) from Moorea island, Society Archipelago, South Pacific Ocean with distinctive valvocopula morphology and linking system C. Riaux Gobin, O.E. Romero, Michel Coste, R. Galzin
}

\section{- To cite this version:}

C. Riaux Gobin, O.E. Romero, Michel Coste, R. Galzin. A new Cocconeis (Bacillariophyceae) from Moorea island, Society Archipelago, South Pacific Ocean with distinctive valvocopula morphology and linking system. Botanica Marina, 2013, 56 (4), pp.339-356. 10.1515/bot-2012-0162 . hal-01123877

\section{HAL Id: hal-01123877 \\ https://hal.science/hal-01123877}

Submitted on 6 Mar 2015

HAL is a multi-disciplinary open access archive for the deposit and dissemination of scientific research documents, whether they are published or not. The documents may come from teaching and research institutions in France or abroad, or from public or private research centers.
L'archive ouverte pluridisciplinaire $\mathbf{H A L}$, est destinée au dépôt et à la diffusion de documents scientifiques de niveau recherche, publiés ou non, émanant des établissements d'enseignement et de recherche français ou étrangers, des laboratoires publics ou privés. 


\section{Catherine Riaux-Gobin*, Oscar E. Romero, Michel Coste and René Galzin}

\section{A new Cocconeis (Bacillariophyceae) from Moorea Island, Society Archipelago, South Pacific Ocean with distinctive valvocopula morphology and linking system}

\begin{abstract}
The study of coral reef diatoms on Moorea Island in the Society Archipelago, South Pacific Ocean revealed a strong representation of the Achnanthales, with many taxa of Cocconeis. One of these Cocconeis, examined by light and scanning electron microscopy, shows a sternum valve (SV) with a close resemblance to the Cocconeis scutellum lineage, whereas the raphe valve (RV) and the valvocopula system are different from that of $C$. scutellum, therefore a new name has been given to it, Cocconeis spina-christi sp. nov. This new taxon has several remarkable features: 1) the RV stria density is, on average, twice as high as that of the SV; 2) the RV valvocopula extended and structurally complex, has large marginal fenestrae, irregular digitiform fimbriae and one longer spine-like fimbria at each apex; and 3) an anchor system between the valvocopula of each valve is observed, consisting of a rounded papilla with transverse furrows lying on each basal RV valvocopula fimbria and fitting into a rounded concavity or cupule - in the corresponding marginal edge of the SV valvocopula. Such an anchor system between valvocopulae seems a characteristic common to several Cocconeis species bearing fimbriae on each valvocopula. The definition and limit of the concept of varieties in the C. scutellum lineage is also addressed.
\end{abstract}

Keywords: Cocconeis; Pacific; tropical reefs; ultrastructure; valvocopula.

\footnotetext{
*Corresponding author: Catherine Riaux-Gobin, Laboratoire d'Excellence CORAIL, USR 3278 CNRS-EPHE, CRIOBE-Université de Perpignan, FR-66860, France, e-mail: catherine.gobin@univ-perp.fr Oscar E. Romero: Instituto Andaluz de Ciencias de la Tierra (CSICUGR), Avenida de las Palmeras 4, 18100 Armilla-Granada, Spain Michel Coste: IRSTEA, 50 avenue de Verdun, FR-33612 Cestas, France

René Galzin: Laboratoire d'Excellence CORAIL, USR 3278 CNRS EPHE, CRIOBE-Université de Perpignan, FR-66860, France
}

Abbreviations: LM: light microscope, RV: raphe valve, SEM: scanning electron microscope, SV: sternum valve.

\section{Introduction}

The architecture and physical attributes of diatom frustules have been reviewed by Hamm et al. (2003) and more recently by Townley (2011), though no particular attention has been given to the cingulum and its role in the robustness of the frustule. However, several studies focussing on the Cocconeidaceae Kützing show the highly variable morphology and structure of the cingulum encountered in this family and its putative functionalities (Holmes et al. 1982, Kobayasi and Nagumo 1985, Round et al. 1990, De Stefano and De Stefano 2005). Holmes et al. (1982) stated that the 'morphology of the fimbriate valvocopulae varies in, and is diagnostic of each taxon'; they also stated that valvocopulae with fimbriae on both valves were only found in Cocconeis scutellum Ehrenberg though some other Cocconeis taxa also possess such a feature (see below).

Within the Cocconeidaceae, the frustule of Campyloneis Grunow has one of the most complex siliceous internal structures, which is composed of a reticulate valvocopula that is extended onto the valve surface of both valves, with a tight anchor system linking both valves and the pars interior of the valvocopulae as well as the copulae (De Stefano et al. 2003). Extended valvocopulae are also features shared by species of Amphicocconeis De Stefano et Marino (De Stefano and Marino 2003), though its copulae are apparently not linked inter se (De Stefano and Marino 2003, Riaux-Gobin et al. 2011a). According to De Stefano and Marino (2003), Amphicocconeis is a recently described genus that is possibly at the evolutionary base of the Cocconeidaceae because its raphe system and valvocopulae are considered to be ancestral characters.

The frustule structure of Cocconeis Ehrenberg is also diverse and complex and has been described several times (e.g., Holmes et al. 1982, Kobayasi and Nagumo 1985, De Stefano et al. 2000, De Stefano and De Stefano 2005, De Stefano and Romero 2005). Different cingulum arrangements exist in Cocconeis, ensuring the robustness of the frustule, and the valvocopulae are likely to play an important role in maintaining the adhesion between the valves. 
As shown by De Stefano and Romero (2005), non-fimbriate valvocopulae exist on both valves in, among others, C. contermina Schmidt, C. pseudomarginata Gregory and C. subtilissima Meister. In the latter, the valvocopulae are often open with no apparent connection between them. However, a particular linking system between the valvocopula pars interior and the valves has been noticed. For example, on the advalvar side of the RV valvocopula of $C$. pseudomarginata, small knobs fit into the concave structure of each RV areola (De Stefano and Romero 2005, pl. 31, figure 2). Additionally, the presence of ligulae may enhance the strength of the copula system (De Stefano and Romero 2005, pl. 31, Figure 4).

In other species, a fimbriate valvocopula exists only on one valve, usually the RV, as can be seen in C. multiperforata De Stefano, Marino et Mazella (De Stefano and Romero 2005, pl. 24, figure 10), whereas the SV valvocopula lacks fimbriae. In some species, such as $C$. californica Grunow, the RV valvocopula has digitate fimbriae, whereas the SV valvocopula has only wavy and short fimbriae (Riaux-Gobin and Romero 2003, pl. 8, figure 7).

Valvocopulae with well-developed digitate fimbriae on both valves are characteristics typical of, though not exclusive to, the $C$. scutellum lineage (Holmes et al. 1982, Lange-Bertalot and Krammer 1989, De Stefano et al. 2008). Several other species also show this feature, such as $C$. alucitae Riaux-Gobin et Compère (Riaux-Gobin and Compère 2008), C. antiqua Tempère et Brun, C. barleyi Frankovich et De Stefano, C. britannica Naegeli ex Kützing (cf., De Stefano and Romero 2005), C. imperatrix A. Schmidt sensu Manguin (cf., Riaux-Gobin and Romero 2003), C. nagumoi Suzuki (Suzuki and Tanaka 2006), C. sagaraensis Suzuki (Suzuki et al. 2005), C. cf. schmidtii Heiden (cf., Riaux-Gobin and Romero 2003) and C. shikinensis Suzuki (Suzuki et al. 2001). Given recent SEM observations, the idea that $R V$ and SV valvocopulae possessing digitate fimbriae are unique to $C$. scutellum can no longer be supported (Holmes et al. 1982).

Small embossed structures are present on the abvalvar side of the RV valvocopula of several Cocconeis that are named papillae by De Stefano et al. (2008). These papillae have a variable shape and ornamentation (i.e., with frequent transverse furrows) and their role as a possible connection to a part of the frustule is discussed below.

We here describe a new tropical diatom species, $C$. spina-christi Riaux-Gobin, Romero, Coste et Galzin, from Moorea Island of the Society Archipelago in the South Pacific that shows unique valve and valvocopula features allowing it to be split from the $C$. scutellum lineage. Several varieties of $C$. scutellum recently described with different features from those of the nominate variety (De Stefano et al. 2000, 2008) are also analysed and compared (Table 1). The valvocopula system of this new species and its possible function are discussed.

\section{Materials and methods}

Numerous sites were investigated for diatom material in Moorea Island of the Society Archipelago, South Pacific Ocean. Diatom samples containing the new Cocconeis species were collected from four sites (Figure 1), including 1) intertidal beach sand from Cook Bay $\left(17^{\circ} 30^{\prime} .431 \mathrm{~S}\right.$, $149^{\circ} 49^{\prime} .222 \mathrm{~W}$ ) on October 16, 2010 (sample COOK 1), 2) intertidal surface sediment near Afareaitu $\left(17^{\circ} 33^{\prime} .244\right.$ S, $149^{\circ} 47^{\prime} .353 \mathrm{~W}$ ) on October 20, 2010 (sample Pointe Tiaraha), 3) surface waters from Temae Lake $\left(17^{\circ} 28^{\prime} \mathrm{S}\right.$, $149^{\circ} 45^{\prime}$ W) on May 6, 1983 (sample Temae Lake) and 4) surface waters from Vaiare Bay $\left(17^{\circ} 31^{\prime} \mathrm{S}, 149^{\circ} 46^{\prime} \mathrm{W}\right)$ on May 7, 1983 (sample Vaiare Bay). Samples were preserved in formaldehyde (10\% final concentration). For light microscope (LM) examination, diatom samples were washed with distilled water to remove salts, treated with $30 \% \mathrm{H}_{2} \mathrm{O}_{2}$ for $2 \mathrm{~h}$ at $70^{\circ} \mathrm{C}$ to remove the organic matter, rinsed several times in distilled water, alcohol-desicated and mounted on glass slides using Naphrax $^{\circledR}$ (Brunel Microscopes Ltd., Wiltshire, UK) or Hyrax ${ }^{\circledR}$ (Penn and Ruedrich, New York City, NY, USA). Diatom slides were examined with an Olympus BX41 (Olympus IBERIA, S.A.U., Barcelona, Spain) light microscope or a Zeiss Axiophot 200 (Carl Zeiss SAS, Le Pecq, France) with differential interference contrast (DIC) optics and photographed with a Canon PowerShot G6 digital camera (Instituto Andaluz de Ciencias de la Tierra, Granada, Spain and CRIOBE-Perpignan University, France). For SEM examination, preserved field samples were filtered through 1- $\mu \mathrm{m}$ Nuclepore filters and rinsed twice with deionised (milliQ) water to remove salts. Filters were air-dried and mounted onto aluminum stubs before being coated with a gold-palladium alloy (EMSCOP SC 500 sputter coater, Elexience, Verrières-le-Buisson Cédex, France) and examined with either a Hitachi S-4500 SEM (Elexience, Verrières-le-Buisson Cédex, France) operated at $8 \mathrm{kV}$ (Université de Perpignan, Perpignan, France) or a Zeiss EVO 50 environmental SEM (Carl Zeiss NTS GmbH, Oberkochen, Germany) operated at $10 \mathrm{kV}$ (Université de Bordeaux I, France). Temperature, conductivity, $\mathrm{pH}$ and dissolved oxygen were measured in Cook Bay in the water overlying the sampled sediment (COOK1) using a YSI 600QS Quick Sample System probe (ANHYDRE, Vireux Molhain, France). 


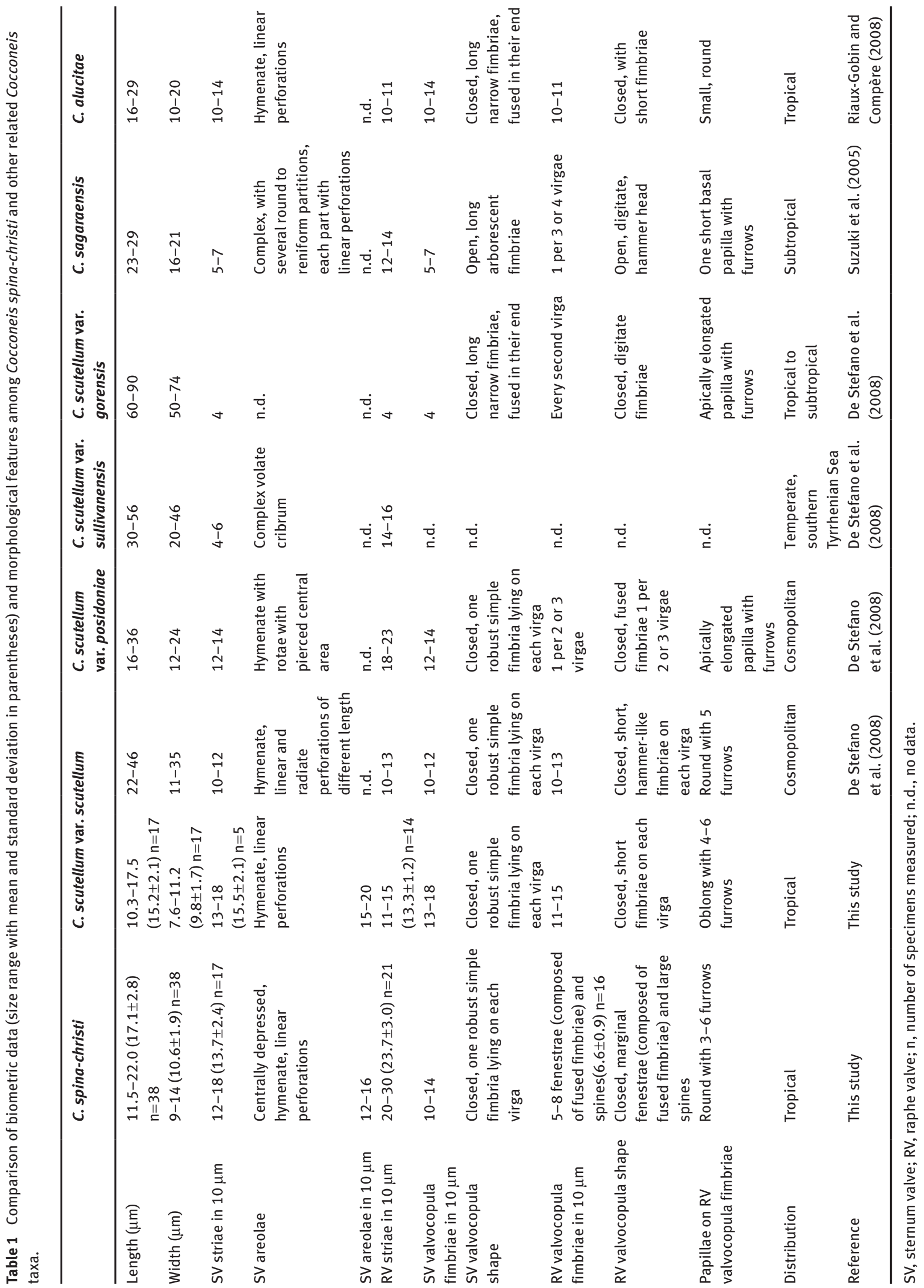




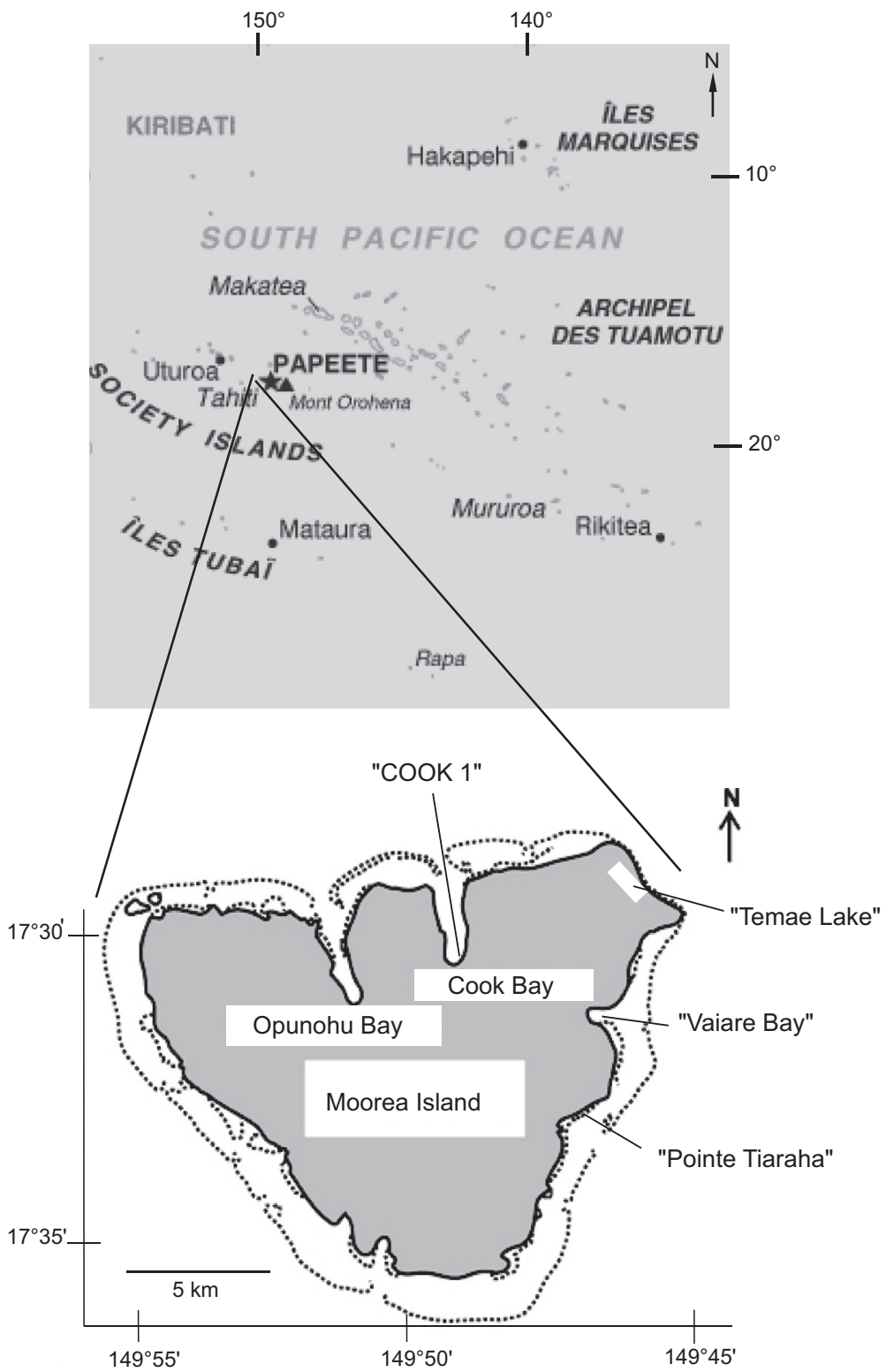

Figure 1 Location of the Society Archipelago in the South Pacific Ocean and map of Moorea Island showing the extent of the coral reef (dotted line) and the four sampling sites visited in May 1983 (Temae Lake and Vaiare Bay) and October 2010 (COOK 1 and Pointe Tiaraha).

The general terminology used for the diatom frustules follows Anonymous (1975) and Ross et al. (1979). Various terminologies have been proposed for the valves of the Achnanthales. Round et al. (1990) uses P-valve for the valve without a raphe and R-valve for the valve with a raphe, whereas Mizuno (1987) uses araphid valve (AV) and raphid valve (RV) and De Stefano et al. (2008) use sternum valve (SV) and raphe-sternum valve (RSV). Following the Greek origin of the word 'sternum', it is proposed to designate the valve with a raphe as the raphe valve (RV) and the valve without a raphe as the sternum valve (SV).

\section{Results}

To permanently preserve SEM aluminium stubs, they are referenced and kept in an air-dried container at CRIOBEUniversité de Perpignan, France. The LM illustration of the new taxon does not give a clear view of the valvocopula system (Figures 5, 8-10), which is one of the main features for establishing Cocconeis spina-christi as a new species. The $\mathrm{RV}$ striation is hardly visible in LMs (Figures 6, 7). Therefore, according to Article 37.5 of the International Code of Botanical Nomenclature (McNeil et al. 2006), the holotype should 
be designated from original SEM images that clearly show these diagnostic features. Isotypes are designated from slides made from the sample in which the new taxon was observed. All morphometric data are presented in Table 1.

\section{Cocconeis spina-christi Riaux-Gobin, Romero, Coste et Galzin sp. nov. (Figures 2-57)}

\section{Descriptio}

Valvae minutae et ellipticae, 11.5-22 $\mu \mathrm{m}$ longae, 9-14 $\mu \mathrm{m}$ latae, apicibus rotundatis. Sternumvalva: valva convexa et robusta, morphologia similaris Cocconeis scutellum SV. Striae radiantes (12-18 in $10 \mu \mathrm{m})$, monoseriatae prope sternum, biseriatae ad triseriatae prope marginem. Areolae rotundatae (12-16 in $10 \mu \mathrm{m})$ regulariter dispositae in axiale striis, areolae praesentes ad polos, externe hymenio stellatis rimulis rectis perforato clausae, cum centrali parte leniter concava. Interne visae areolae hymenio tholiformi clausae, stellatis rimulis rectis perforato. Area axialis mediocris et recta. Valvocopula robusta et non aperta, cum regulariter protractis fimbriis ad virgas positis. Raphevalva: valva tenuis, plana ad leniter concava. Striae densae et radiantes, cum regularibus interstriis (20-30 in $10 \mu \mathrm{m}$ ), uniseriatae usque ad marginalem zonam hyalinam et biseriatae de hinc. Areolae rotundatae et parvae (26-35 in $10 \mu \mathrm{m}$ ), externe hymenio stellatis rimulis rectis perforato clausae, praesentes ad polos. Area axialis anguste linearis. Raphe recta filiformis; pori centrales oppositi et approximati; pori externi terminales simpliciter dilatati et a margine minime disjuncti. Interne, raphe in brevem helictoglossam terminans. Zona hyalina angusta et elata, ad marginem locata. Insignis robusta et non aperta valvocopula, cum marginalibus largis fenestris, rotundatis parvis papillis et spinaformibus fimbriis non aequabiliter positis; una latior spina ad utrosque polos.
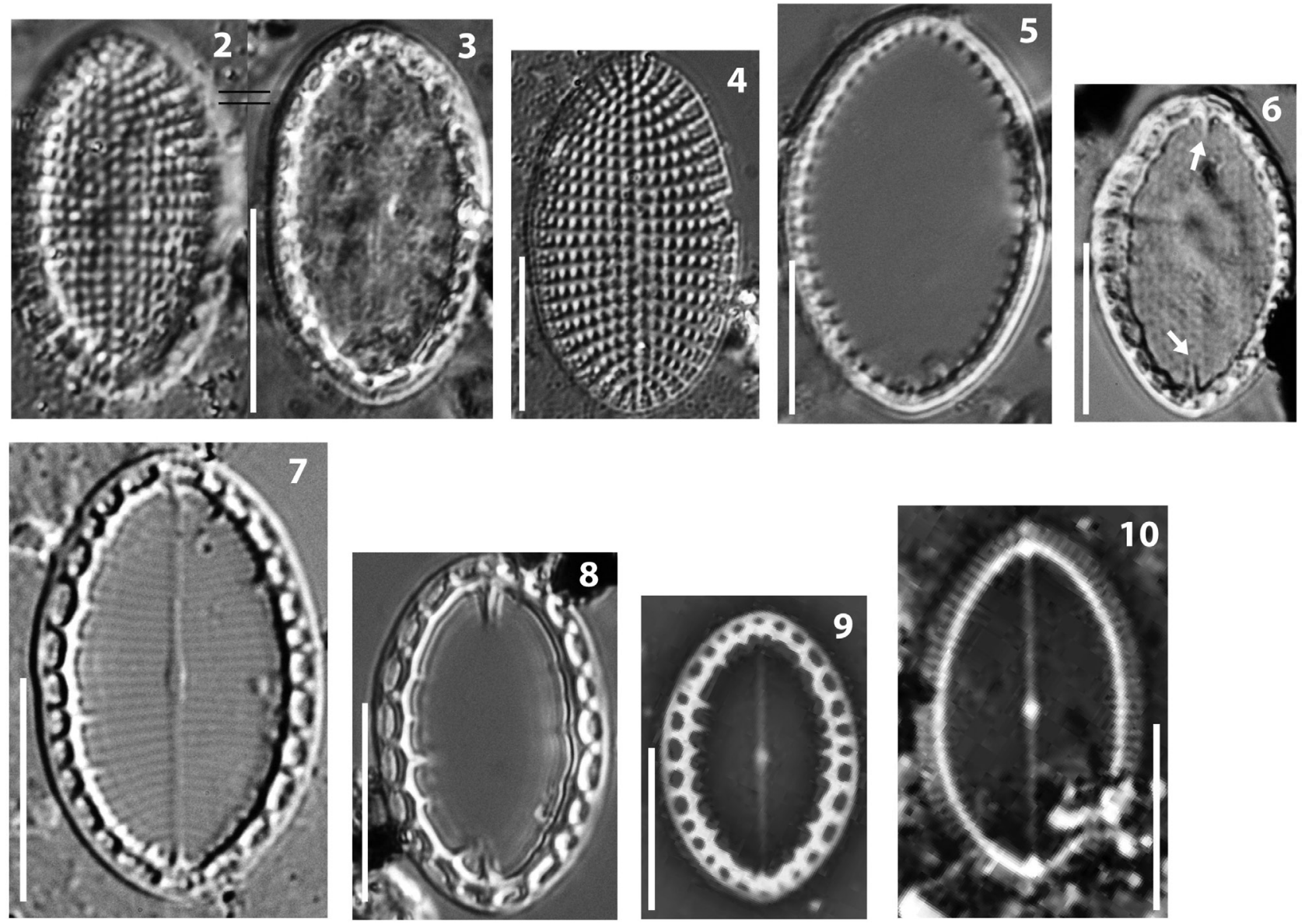

Figures 2-10 Type material of Cocconeis spina-christi sp. nov. from Cook Bay, Moorea Island, LM. (2, 3) Sternum valve at two different focal depths, showing striation (2) and attached valvocopula (3). (4) Detached sternum valve. (5) Detached valvocopula. (6) Sternum valve with complete valvocopula system still attached; note the two long spines on the apices (arrows). (7) Raphe valve with attached valvocopula. (8) Detached valvocopula of the raphe valve showing marginal fenestrae and inward irregular spines. (9) Raphe valve with attached valvocopula. (10) Raphe valve without valvocopula, showing a marginal hyaline rim. Scale bars $=10 \mu \mathrm{m}$. 

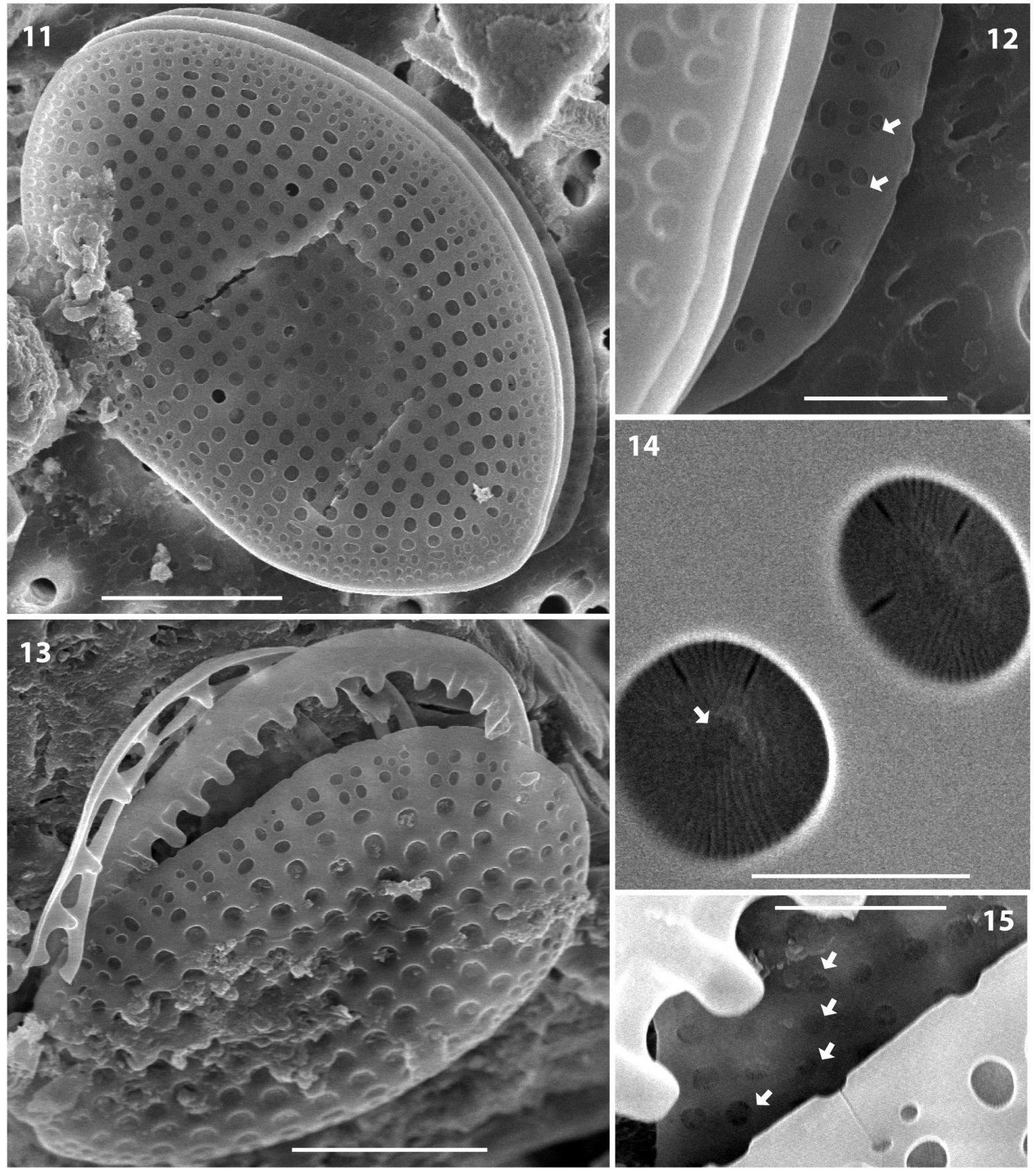

Figures 11-15 Type material of Cocconeis spina-christi sp. nov. from Cook Bay, Moorea Island, SEM. (11) Sternum valve in external view. (12) Internal view of raphe valve margin showing dense striation (arrows). (13) Broken frustule showing pieces of raphe valve valvocopula and sternum valve valvocopula partially attached to the sternum valve. (14) Hymenate areolae of sternum valve showing central depression (arrow). (15) Detail of raphe valve striation (arrows). Scale bars $=6 \mu \mathrm{m}$ (Figure 11); $4 \mu \mathrm{m}$ (Figure 13); $1 \mu \mathrm{m}$ (Figures 12 and 15 ); and $500 \mathrm{~nm}$ (Figure 14).

\section{Holotype}

SEM stub no. 1 10/06/2011 deposited in the C. Riaux-Gobin collection at the Laboratoire d'Excellence CORAIL, CRIOBE-Université de Perpignan, France. The holotype specimen is illustrated in Figure 45.

\section{Isotypes}

Slides BM101626, Natural History Museum, London, UK, ZU8/15, Hustedt collection, Alfred-Wegener-Institut für Polar- und Meeresforschung, Bremerhaven, Germany, and MOOR1, C. Riaux-Gobin collection, 

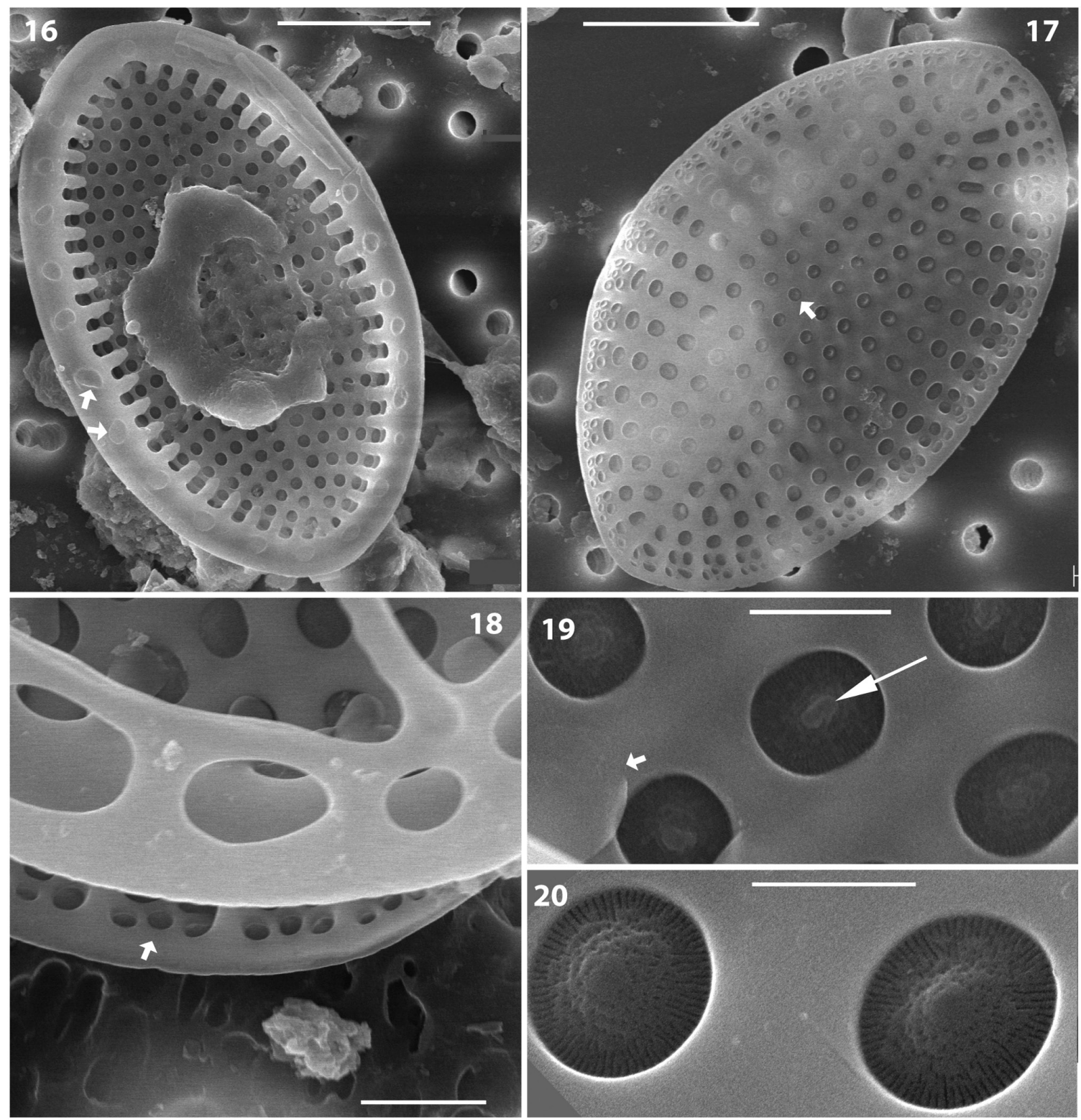

Figures 16-20 Specimens of Cocconeis spina-christi sp. nov. from Temae Lake (Figure 16) and Cook Bay, Moorea Island (Figures 17-20). (16) Sternum valve in internal view showing variously oriented anchor points or cupules (arrows) on the margin of the digitate-fimbriate valvocopula. (17) Sternum valve in internal view; note one row of slightly smaller areolae (arrow) bordering the sternum. (18) Internal view of part of a sternum valve showing marginal triseriate striation (arrow) and a raphe valve valvocopula with large fenestrae. (19) Sternum valve areolae in internal view, with a central dome (long arrow) and a fimbria of the valvocopula lying on a virga (short arrow). (20) Sternum valve areolae in internal view showing radiate slits and a central dome. Scale bars $=5 \mu \mathrm{m}$ (Figures 16, 17); $1 \mu \mathrm{m}$ (Figure 18); $600 \mathrm{~nm}$ (Figure 19); and $400 \mathrm{~nm}$ (Figure 20).

Laboratoire d'Excellence CORAIL, CRIOBE-Université de Perpignan.

\section{Type locality}

Sample COOK1 from intertidal beach sand, Cook Bay,

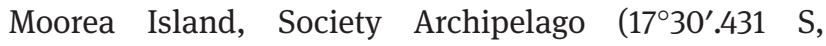

$\left.149^{\circ} 49^{\prime} .222 \mathrm{~W}\right)$. Collected by C. Riaux-Gobin, October 16 , 2010.

\section{Etymology}

The specific epithet refers to the spine-bearing valvocopula, which resembles Christ's crown of thorns. 

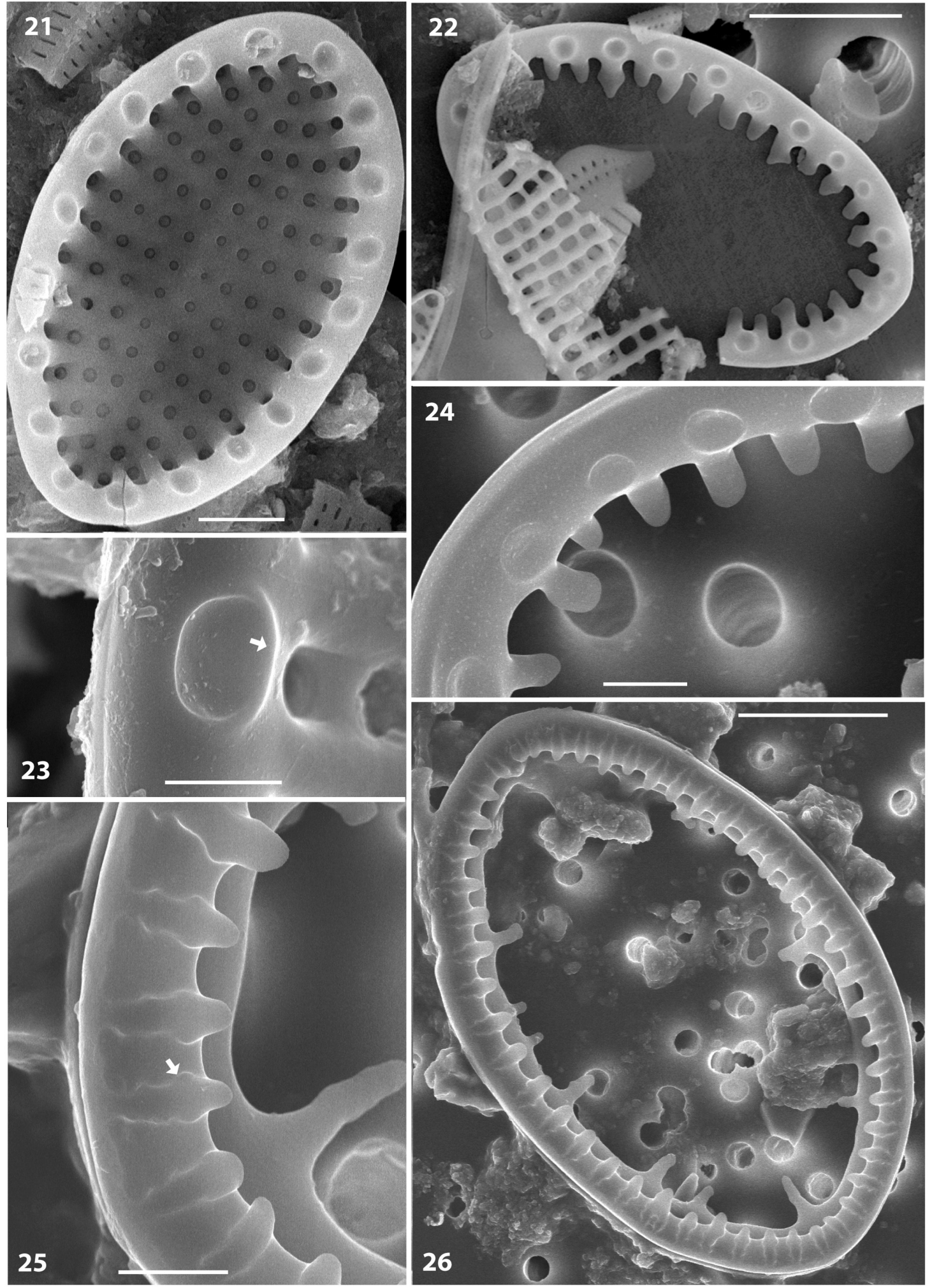

Figures 21-26 Specimens of Cocconeis spina-christi sp. nov. from Temae Lake (Figures 21 and 22) and Cook Bay, Moorea Island (Figures 23-26).(21) Sternum valve in internal view, with rounded anchor points, or cupules, on the valvocopula margin. (22) Broken valvocopula of a sternum valve with short fimbriae. (23) Cupule with an elevated rim (arrow) on its inward face. (24) Abvalvar view of a sternum valve valvocopula. (25) Advalvar view of a sternum valve valvocopula with undulated base of fimbriae (arrow); note valvocopula of the raphe valve still attached underneath. (26) Valvocopula of both sternum and raphe valves showing a large apical spine on the raphe valve valvocopula. Scale bars=5 $\mu \mathrm{m}$ (Figures 22 and 26); $2 \mu \mathrm{m}$ (Figure 23); $1 \mu \mathrm{m}$ (Figures 24 and 25); and $700 \mathrm{~nm}$ (Figure 23). 

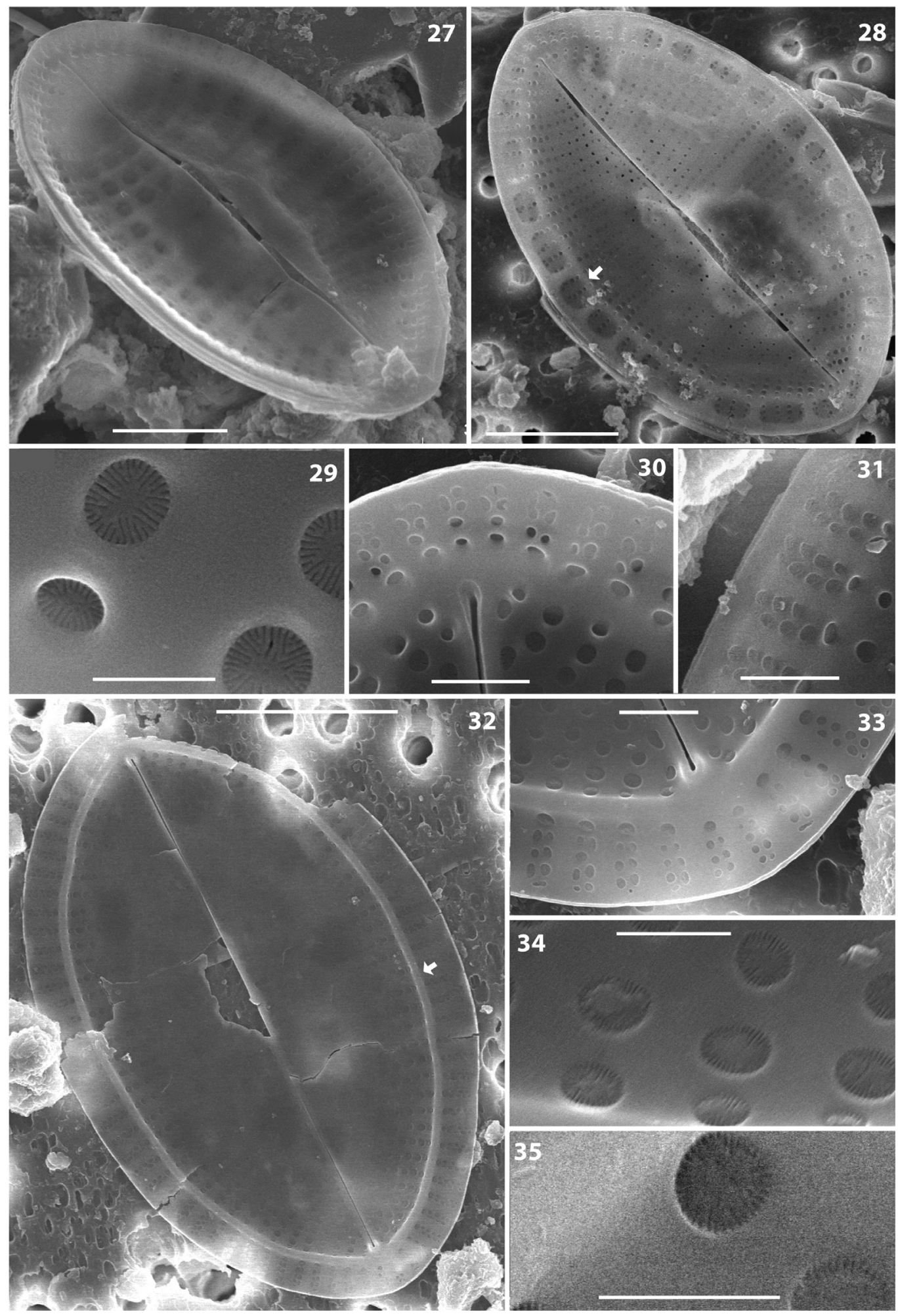

Figures 27-35 Type material of Cocconeis spina-christi sp. nov. from Cook Bay, Moorea Island, SEM external (Figures 27-31) and internal views (Figures 32-35).(27) Frustule showing the raphe valve with dense striation, the large areolae of the sternum valve underneath and the low cingulum. (28) Raphe valve showing the marginal fenestrae of the valvocopula. (29) Raphe valve hymenate areolae with radiate slits. (30) Apex of the raphe valve showing monoseriate striation becoming biseriate at the margin beyond the rim. (31) Biseriate striation with areolae opposite or alternate. (32) Raphe valve showing a marginal elevated rim (arrow) (33) Apex of raphe valve, with biseriate marginal striae and helictoglossa. $(34,35)$ Hymenate areolae of raphe valves with short marginal radiate slits and a central area lacking slits. Scale bars $=6 \mu \mathrm{m}$ (Figures 28 and 32); $3 \mu \mathrm{m}$ (Figure 27); $1 \mu \mathrm{m}$ (Figures 30, 31 and 33); $400 \mathrm{~nm}$ (Figures 34 and 35); and $300 \mathrm{~nm}$ (Figure 29). 

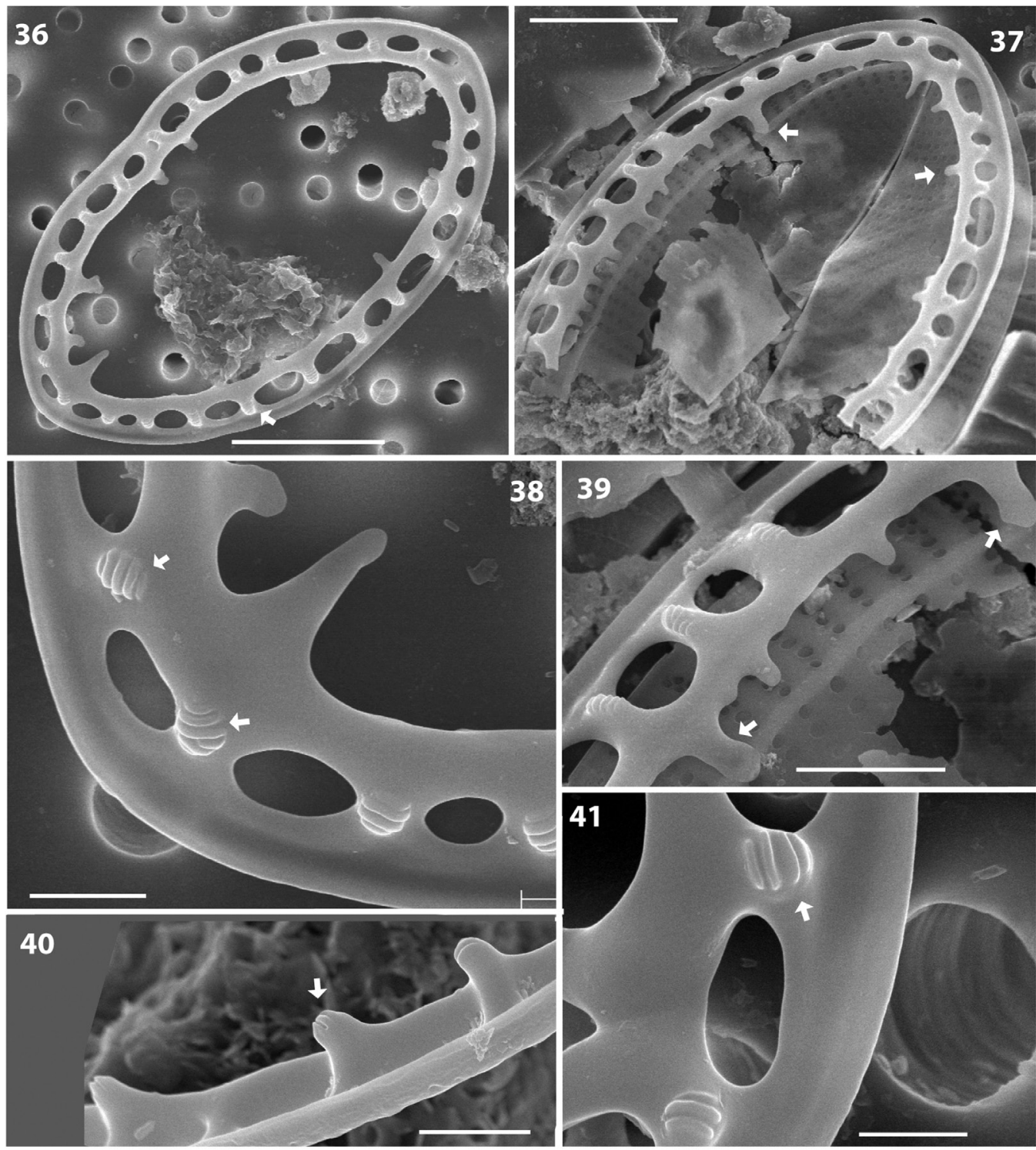

Figures 36-41 Type material of Cocconeis spina-christi sp. nov. from Cook Bay, Moorea Island, abvalvar views of the raphe valve valvocopula with SEM. (36) Valvocopula with marginal fenestrae and irregular, inwardly oriented, marginal spines; note the papillae on midfimbriae (arrow). (37) Broken valvocopula still attached to the raphe valve, with irregular inwardly oriented spines (arrows). (38) Variation in the furrow orientation (arrows) of rounded papillae on the valvocopula. (39) Detail of irregular inwardly oriented spines (arrows) on the valvocopula of raphe valve. (40) Elevated papillae (arrow) on the valvocopula. (41) Papilla with transverse furrows (arrow). Scale bars=5 $\mu \mathrm{m}$ (Figures 36 and 37); $2 \mu \mathrm{m}$ (Figure 39); $1 \mu \mathrm{m}$ (Figures 38 and 40); and $600 \mathrm{~nm}$ (Figure 41).

\section{Morphology}

The valve is small-sized, and the outline is elliptical (Figures 2-10).

\section{Sternum valve (SV)}

Externally, the valve face is convex (Figures 11, 13 and 18 , arrow) and strongly silicified. The sternum is narrow and linear (Figures 4 and 11). The striae are radiate, uniseriate close to the sternum and bi- to triseriate near the margin (Figures 4, 11 and 13), with lower stria density than in the RV (Figures 12 and 15, arrows). The areolae are rounded, regularly axially arranged and also present at apices (Figure 17). One apical row of smaller-sized areolae is often present along the sternum (Figure 11), as also shown on internal view (Figure 17, arrow). The areolae are externally occluded by hymenes, with linear perforations radiating from a depressed central part (Figure 14, arrow). 

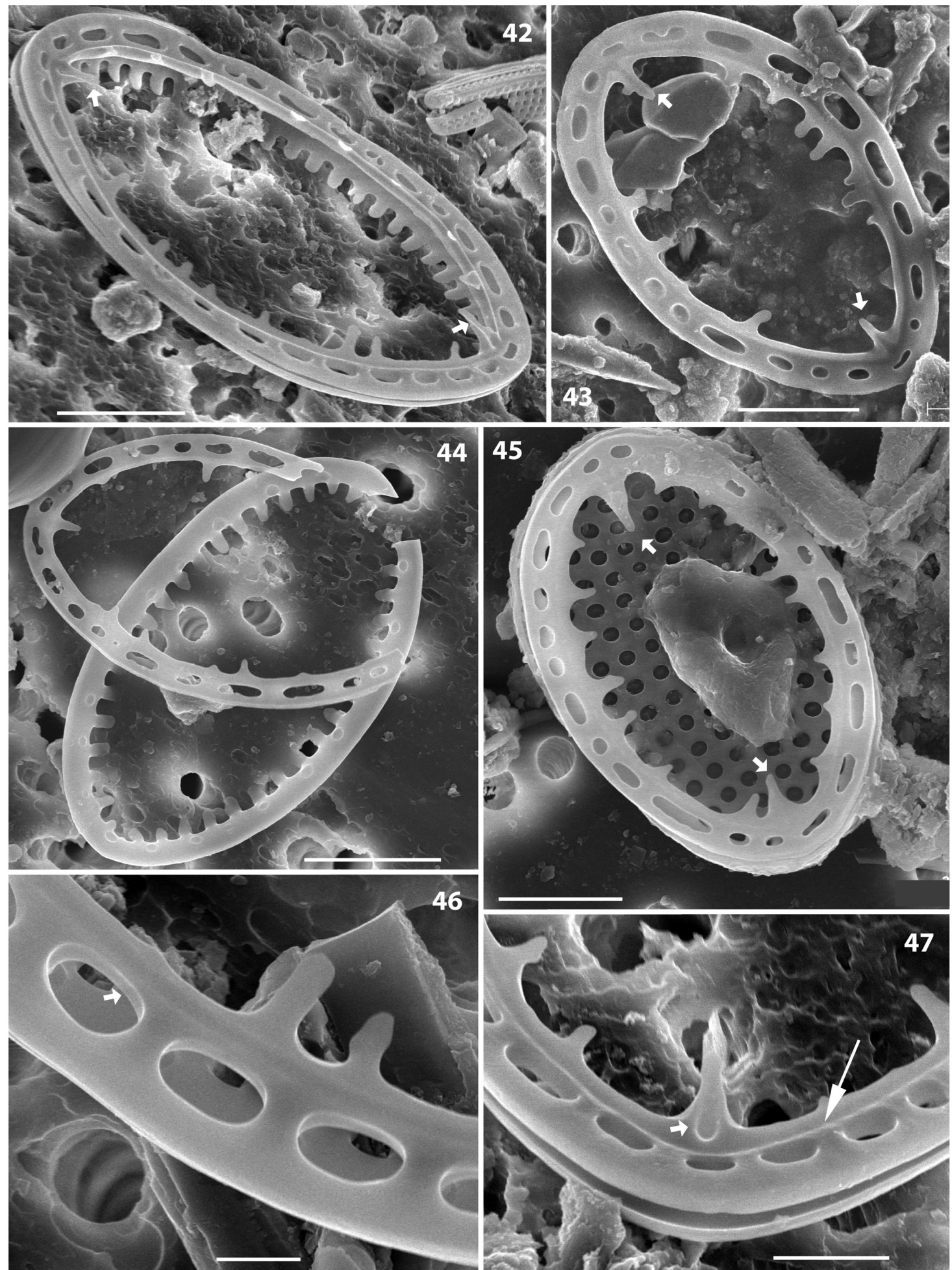

Figures 42-47 Type material of Cocconeis spina-christi sp. nov. from Cook Bay, Moorea Island, advalvar views of raphe valve valvocopula in SEM. (42) Valvocopula of both valves still attached together, with large apical spines (arrows). (43) Valvocopula with two large apical spines (arrows). (44) Broken valvocopulae. (45) Holotype specimen showing irregular inwardly oriented spines and two larger apical spines (arrows) on the valvocopula. (46) Section of valvocopula showing marginal fenestrae. Note the thickness of fenestrae (arrow) and irregular position of inwardly oriented spines. (47) Detail of sunken base of the apical spine (short arrow) and sunken rim (long arrow) running around the circumference of the valvocopula. Scale bars $=5 \mu \mathrm{m}$ (Figure 42); $4 \mu \mathrm{m}$ (Figures 43 and 44); $3 \mu \mathrm{m}$ (Figure 45); $2 \mu \mathrm{m}$ (Figure 47); and $1 \mu \mathrm{m}$ (Figure 46). 

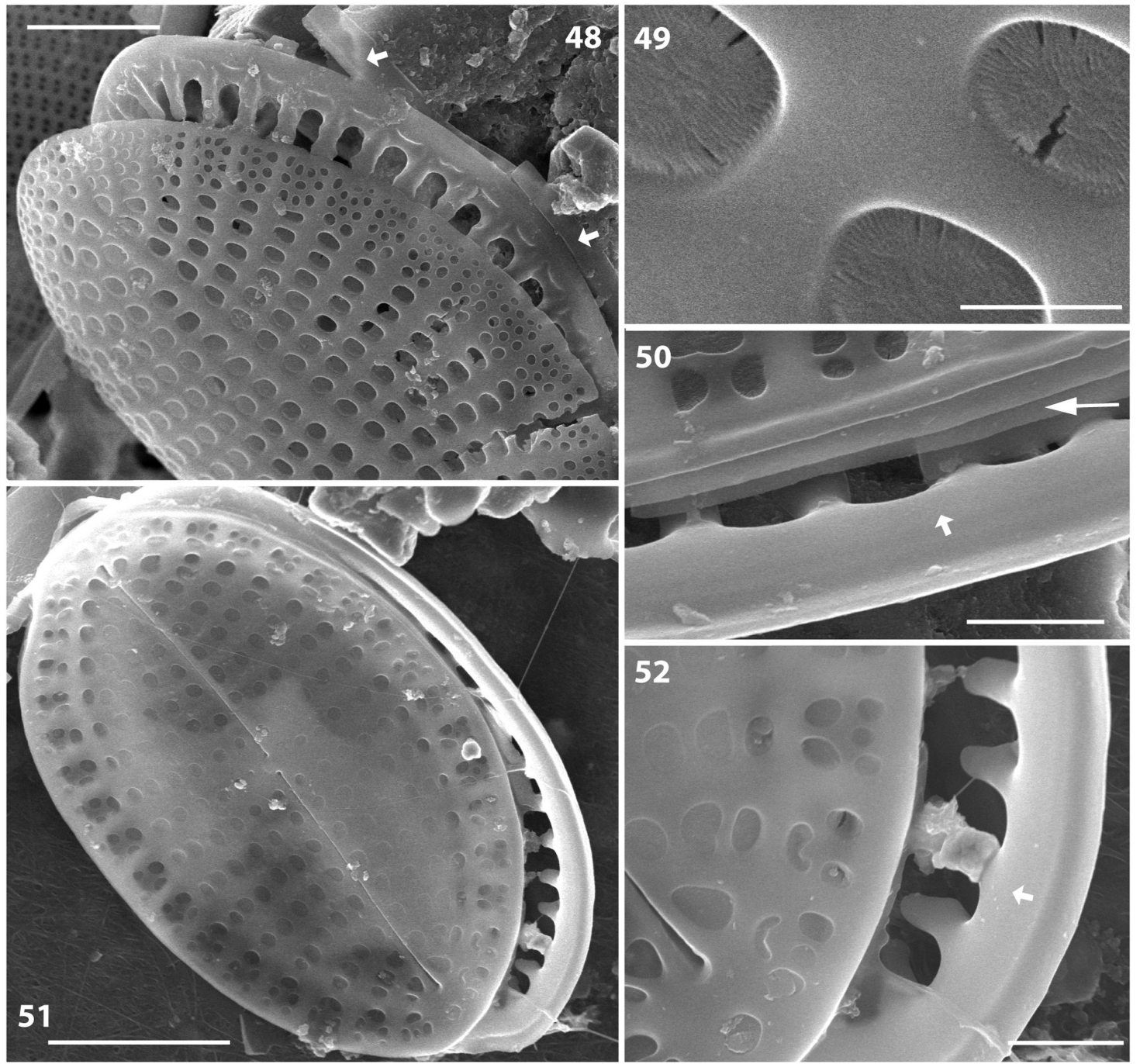

Figures 48-52 Specimens of Cocconeis scutellum var. scutellum from Cook Bay, Moorea Island, SEM.(48) External view of sternum valve with the valvocopula in advalvar view; note the narrow detached intercalary connecting band (arrows). (49) External view of hymenate areolae with no central depression. (50) Margin of sternum valve valvocopula in abvalvar view lacking anchor points (arrow); note narrow intercalary connecting band (long arrow). (51) External view of a raphe valve, with the valvocopula in abvalvar view. (52) Lack of anchor points (arrow) on sternum valve valvocopula. Scale bars=4 $\mu \mathrm{m}$ (Figures 48 and 51); $1 \mu \mathrm{m}$ (Figures 50 and 52); and $400 \mathrm{~nm}$ (Figure 49 ).

Internally, the areolae are occluded by domed hymenes with linear radiating marginal perforations and shorter ones at the centre (Figures 19 and 20). The valvocopula is robust and closed, with rather regular digitate fimbriae (Figures 5 and 24), from which the edge is lying on each virga (Figures 16 and 21). The abvalvar side of the valvocopula shows ovoid to ellipsoid cupules with various axial orientations (Figure 16, arrows). These cupules are more or less regularly arranged all over the margin (Figures 16, 21-24) and often show raised edges (Figure 23, arrow). On the advalvar side of the valvocopula (Figure 26), the bases of the fimbriae are slightly sunken with an undulated margin (Figure 25, arrow).

\section{Raphe valve (RV)}

Externally, the valve is weakly silicified, flat or slightly concave (Figure 27). Striae are dense, regularly spaced and radiate (Figures 7, 10, 27, 28 and 32) uniseriate up to the marginal hyaline rim. Between the rim and the valve margin, the striae are biseriate with alternating areolae (Figures 30 and 31). The RV striae are slightly denser close to the apices. The central area is very reduced or small (Figure 28). The areolae are occluded by hymenes located close to the valve surface or slightly depressed, with marginally and radially arranged linear perforations of different lengths (Figures 29, external view, 34 and 35, internal 

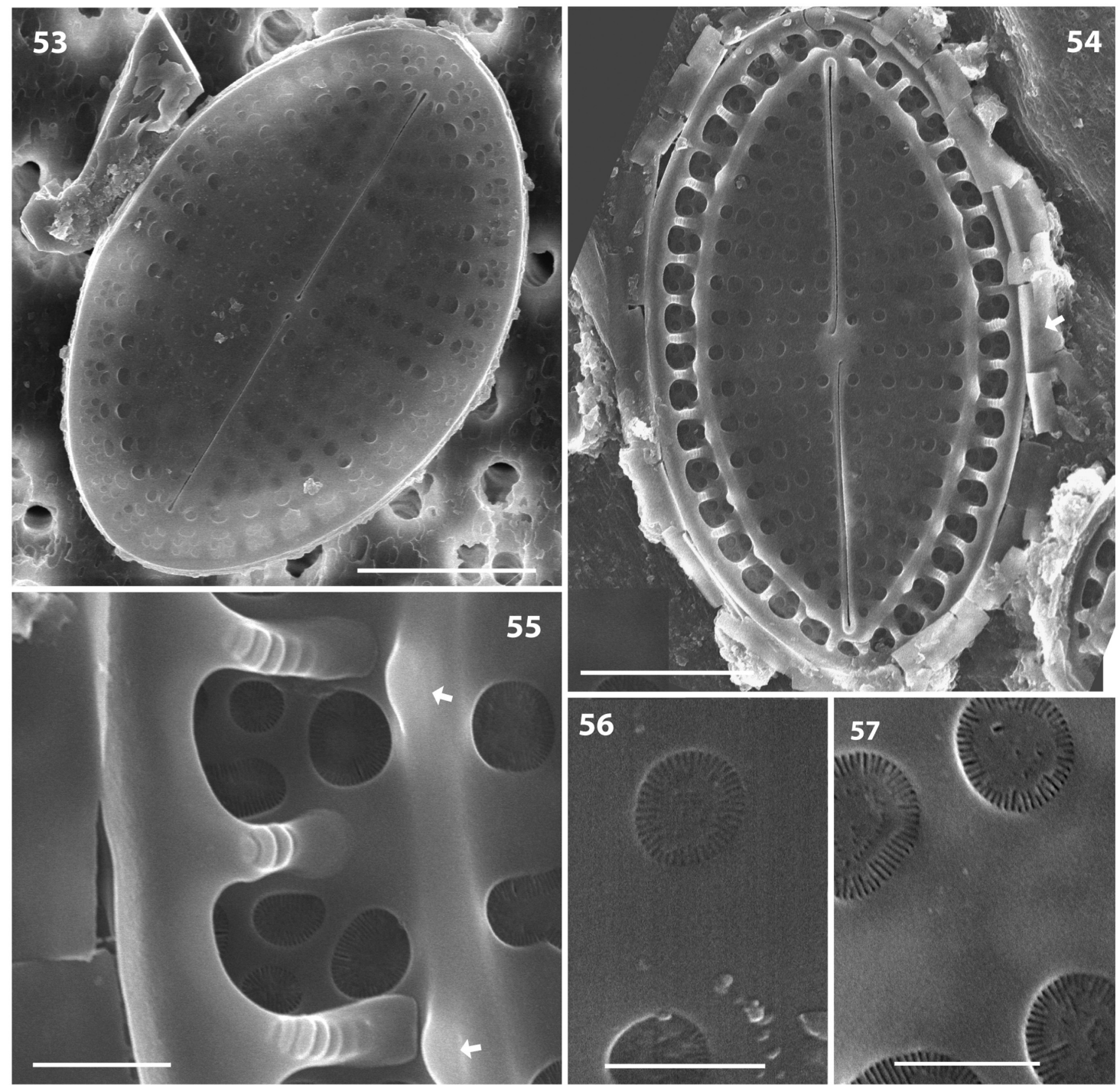

Figures 53-57 Specimens of Cocconeis scutellum var. scutellum from Cook Bay, Moorea Island, SEM. (53) Raphe valve in internal view. (54) Internal view of raphe valve with valvocopula showing regularly spaced fimbriae, irregularly spaced bulging on marginal rim and raised helictoglossae; note the presence of a broken cingular band (arrow). (55) Detail of valvocopula attachment to raphe valve; note the oblong papillae along the fimbriae with numerous furrows and the pegged ending of each fimbria lying slightly under the elevated marginal rim on each virga as well as on reinforcements on the rim (arrows). (56) External view of hymenate areolae of raphe valve. (57) Internal view of hymenate areolae of raphe valve. Scale bars=4 $\mu \mathrm{m}$ (Figures 53 and 54); $600 \mathrm{~nm}$ (Figure 55); and $400 \mathrm{~nm}$ (Figures 56 and 57).

views). Areolae are also present at apices. The axial area is narrow and linear. The raphe is filiform and straight, with proximal raphe endings approximate and not bent, and distal raphe endings simple (not inflated) and terminating near the valve margin (Figure 30). Internally, the raphe is bordered by slightly raised ribs (Figure 32). Small helictoglossae and a raised narrow hyaline marginal rim are present (Figures 10, 32 and 33). The cingulum is only composed of the two valvocopulae with no additional connecting band (Figures 42, 44 and 47). The RV valvocopula is thick (Figure 46, arrow), remarkably well developed and closed, with marginal subquadrangular to ovoid large fenestrae formed by the junction and fusion of two narrow fimbriae (Figures 7-9 and 36-39). On the abvalvar side of each fimbria, a rounded and elevated papilla (Figure 40, arrow), ornamented with three to six furrows, is present (Figures 38-41). The inner edge of the valvocopula shows spine-like fimbriae of different size and location (Figures 7-9 and 37, arrows). At each apex of the RV valvocopula, a larger spine (Figures 6, arrows, 38, 43 and 45, arrows), sunken on its advalvar side (Figure 47, short arrow), is usually present. A groove runs all over the RV valvocopula on its advalvar side (Figure 47, long arrow). 


\section{Ecology}

Cocconeis spina-christi has been recorded in different locations on Moorea Island. It was abundant in the beach sand of Cook Bay (salinity: 35.3, conductivity: $58.1 \mu \mathrm{S} \mathrm{cm}^{-1}$, dissolved oxygen: $73.8 \%$ measured during the 2011 dry season), in plankton samples from Temae Lake, a freshwater to brackish environment (with bottom marine resurgences as mentioned by Faissole 1988) and at a brackish to marine coastal site in Vaiare Bay. This new species is probably epipsammic on coral sand grains. It remains to be investigated whether $C$. spina-christi is restricted to high-salinity environments.

\section{Cocconeis scutellum Ehrenberg (Figures 48-57)}

Specimens of Cocconeis scutellum were found as epiphytes on filamentous green macroalgae in Cook Bay, Moorea Island. Except for its small size, the morphological features and biometric data of these specimens agree with the description of the nominate variety (De Stefano et al. 2008). Except for the flat areola occlusion (Figure 49), the $\mathrm{SV}$ in specimens of $C$. scutellum from Moorea Island shows a strong resemblance with that of $C$. spina-christi. The SV valvocopula of $C$. scutellum does not show distinct anchor points with the RV valvocopula (Figures 50-52). The papillae of the RV valvocopula are oblong and present along all fimbriae (Figure 55). The pegged ending of each fimbria lies slightly under the elevated rim on a virga, with no connection to the rim thickenings (named elongated bumps in De Stefano et al. 2008) (Figure 55, arrows). The cingulum apparently possesses an intercalary band (Figures 48, arrows, 54, arrow, and 55), not observed in C. spina-christi.

\section{Discussion}

\section{Morphological specificities of Cocconeis spina-christi}

Cocconeis spina-christi differs from C. scutellum and its lineage by 1) its small size and 2) a denser striation on RV than on SV, whereas in C. scutellum both valves have more or less the same stria density (Table 1) and 3) a complex RV valvocopula, with a remarkable connection system with the SV valvocopula through round papillae fitting into the cupules on the SV valvocopula.
The SV structure of $C$. spina-christi closely resembles that of $C$. scutellum, except for the areola hymenes, which are slightly concave in their central part from an external view (Figure 14). The new taxon is small in size (Table 1) when compared to previous reports on the type species of C. scutellum and its varieties (e.g., Mizuno 1987, De Stefano et al. 2008, Table 2). Ehrenberg (1838) did not mention the RV stria density in his diagnosis. Hustedt (1931-1959) and (De Stefano et al. 2008, Table 2) recorded both valves of C. scutellum having, on average, the same stria density, with $5-8$ of $10 \mu \mathrm{m}$ in the SV and 7-9 of $10 \mu \mathrm{m}$ in the RV. The RV of the new taxon has a much denser striation than in the SV. Furthermore, the RV stria density of $C$. spinachristi is denser than any reported for $C$. scutellum and its varieties (De Stefano et al. 2008).

The RV of $C$. spina-christi shows some resemblance with that of $C$. scutellum var. posidoniae De Stefano, Marino et Mazella and var. sullivanensis De Stefano (De Stefano et al. 2008), except for the stria density. Nevertheless, the SV of $C$. spina-christi is different from those of the two latter taxa.

Another distinctive feature that distinguishes C. spina-christi from C. scutellum is the RV valvocopula and its connecting system with the SV valvocopula. The SV valvocopula is closed and robust and has the classical features reported in $C$. scutellum, consisting of more or less regular finger-shaped fimbriae, each matching a virga. On the advalvar part of the SV valvocopula, the slightly sunken base of each fimbria clearly shows an undulated margin (Figure 25), fitting the position of the marginal SV areola, which may reinforce the attachment of the SV valvocopula to the SV. Compared with $C$. scutellum, the presence of deep cupules on the abvalvar part of the SV valvocopula of $C$. spina-christi is a feature unique to this new species. However, the RV valvocopula of C. spina-christi differs greatly from that of C. scutellum in its remarkable extension and complexity. Furthermore, the thickness of the RV valvocopula is more or less equivalent to that of the SV valvocopula and is not thinner or less silicified as described in C. scutellum (De Stefano and De Stefano 2005). The presence of marginal fenestrae in the RV valvocopula of the new species (Figures 42-47) may reinforce the mechanical strength of the girdle system by distributing pressure forces more uniformly all over the valve. The presence of the two long and horizontal spines, oriented inwardly, on the apices of the $C$. spina-christi RV valvocopula, with a sunken base on the advalvar part (Figure 47), is enigmatic in its function, though it might be speculated to reinforce the robustness of the thin and weakly silicified RV. 
The RV valvocopula of $C$. spina-christi resembles that of $C$. scutellum var. posidoniae, but the fimbriae of the former are always fused in a thick and regular crown, whereas this is not always the case in $C$. scutellum var. posidoniae (De Stefano et al. 2008, Figure 124). Furthermore, the large spines of the RV valvocopula of $C$. spinachristi are a unique feature.

\section{Papillae and valvocopula connecting system in Cocconeis}

The occurrence of papillae on the abvalvar part of the RV valvocopula fimbriae in C. spina-christi has been previously reported in C. scutellum (Lange-Bertalot and Krammer 1989, De Stefano et al. 2008) and several of its varieties, except for C. scutellum var. parva (Grunow) Cleve (De Stefano et al. 2008). The shape and number of papillae per fimbria vary among taxa. In C. scutellum fo. 1 sensu Riaux-Gobin and Romero (2003, pl. 28, figure 2) from the Kerguelen Archipelago, five to six small, rounded bosses lacking furrows are described as pearllike thickenings.

The papillae on the RV valvocopula are not exclusive to the $C$. scutellum lineage. They have been reported as oblong with furrows in C. maxima (Grunow) Peragallo and Peragallo (De Stefano et al. 2000, figures 28 and 32), small ovoid in C. sagaraensis (Suzuki et al. 2005, figures 24, 26), ovoid in C. britannica (De Stefano et al. 2000, figure 14) and small and irregular in shape in C. alucitae (RiauxGobin and Compère 2008). Furthermore, De Stefano et al. (2000) and De Stefano and De Stefano (2005) stated that the papillae fit into the interspace of the SV fimbriae. Conversely, it is obvious that the $\mathrm{RV}$ papillae in C. spina-christi fit into cupules on the margin of the SV valvocopula, and this is probably true for many species bearing papillae:

1. Considering the illustration of $C$. britannica in De Stefano et al. (2000, figure 5), small dots with more or less the same density as the SV valvocopula fimbriae can be seen on the SV valvocopula margin. These dots represent the anchor points of the papillae present on the RV valvocopula (De Stefano et al. 2000, figure 14, arrow). The papillae are marginally located on the RV valvocopula, and they cannot physically fit the elongated holes of the SV valvocopula that are positioned far away from the margin (De Stefano et al. 2000, figure 5).

2. In C. sagaraensis, the anchor system of the RV valvocopula is also illustrated (Suzuki et al. 2005, figure 31).
3. In C. scutellum var. posidoniae, five linking points are distinctly visible on the left side of the bottom apex, whereas the SV virgae are denser than these linking points (De Stefano et al. 2000, figure 74). Similarly, the $\mathrm{RV}$ valvocopula fimbriae in C. scutellum var. posidoniae are less dense than on the SV valvocopula (De Stefano et al. 2000, figure 76). In the latter variety, De Stefano et al. (2008, figure 114) described a ring of sharp bumps on the mantle, whereas a better description might be a row of embossed designs overhanging each anchor point on the SV valvocopula.

4. Both C. scutellum var. baldjikiana (Grunow) Cleve and var. clinoraphis Zanon possess an anchor system (De Stefano et al. 2008, figures 41 and 62).

In specimens of $C$. scutellum recorded from Moorea Island (Figures 57 and 58), there is no visible trace of a connection between the valvocopulae (De Stefano et al. 2008, figure 25). Furthermore, an additional cingular band seems to exist, possibly impeding the anchor between the valvocopulae (Figures 50, 54 and 55).

In conclusion, a papilla with well-organised furrows cannot fit into a hole or space between fimbriae as stated by De Stefano et al. (2000) but must, more or less tightly, fit together with a particular surface or concavity. Surprisingly, the mark of a linkage between the valvocopulae has been overlooked in several species bearing fimbriate valvocopulae and papillae (De Stefano et al. 2000, 2008, Suzuki et al.2005). An anchor system seems to be needed for several taxa in the genus Cocconeis. In C. spina-christi, the papillae are rounded with deep furrows, with a clearly raised position in the RV valvocopula (Figure 46), hence making it easier for the anchor to fit into the corresponding rounded cupules located in the SV valvocopula margin. This anchor system may reinforce the strength of the valvocopula system and give it a higher resistance to compression forces.

Within the Cocconeidaceae, such an anchor system between the valvocopulae has been observed only in Campyloneis Grunow (e.g., Round et al. 1990, De Stefano et al. 2003) but with several differences compared to the one described for $C$. spina-christi. In Campyloneis, papillae are present on both valvocopulae, instead of only the RV valvocopula in Cocconeis. They are composed of rugose bosses or a cluster of small bosses in Campyloneis, compared to rows of transverse furrows in Cocconeis. Finally, the anchor points are multiple and distributed all over the wide valvocopulae in Campyloneis, while they are restricted to a marginal section of the valvocopulae in Cocconeis. 


\section{Limitation of the concept of variety in Cocconeis scutellum}

As noted by De Stefano et al. (2008), it is difficult to draw a line between the species and varieties within Cocconeis scutellum. For example, two taxa sharing several valve characteristics were recently described, one as $C$. scutellum var. gorensis from the sub-tropical Rottnest Island, Western Australia (De Stefano et al. 2008) and the other as C. alucitae from the tropical Réunion Island (Riaux-Gobin and Compère 2008). The remarkable SV valvocopula, with very long and thin fimbriae fused at their ends, stimulated the creation of the species alucitae because its structure was very different from that of $C$. scutellum. Furthermore, the sternum and raphe of $C$. alucitae are slightly oblique, whereas in C. scutellum var. gorensis, these structures are straight and follow the apical axis. The stria density on both valves is higher in C. alucitae ( $>10$ in $10 \mu \mathrm{m}$ ) than in C. scutellum var. gorensis ( 4 in $10 \mu \mathrm{m}$ ). The papillae on the $\mathrm{RV}$ valvocopula fimbriae of $C$. alucitae are very small and rounded to ovoid, whereas in $C$. scutellum var. gorensis, they are oblong and present along all fimbriae. In addition, the small siliceous outgrowths on the RV external side of $C$. scutellum var. gorensis are lacking in C. alucitae.

As first reported with LMs, C. scutellum and allied varieties are considered as synonyms forming a large C. scutellum lineage (Mizuno 1987, Table 6). Based on valve shape and stria density, Mizuno (1987, see figures 7-9 and references therein) proposed subdividing this heterogeneous complex into five groups: (1) var. scutellum itself; (2) the taxon characterised by a slightly wider valve than that of var. scutellum and by lower striation densities in both valves (e.g., C. scutellum var. ampliata Grun. as identified by Grunow and Cleve); (3) the taxon characterised by a wider valve than that of var. scutellum but with the same striation densities in both valves as var. scutellum (e.g., $C$. scutellum var. ampliata Grun. as identified by Peragallo and Peragallo); (4) the taxon characterised by a lower striation density in $\mathrm{AV}$ than that of var. scutellum (e.g., $C$. scutellum var. ornata Grun. as identified by Mizuno); and (5) the taxon characterised by a larger valve size than that of var. scutellum and by lower striation density in AV (e.g., C. scutellum var. Morrisii Smith as identified by Peragallo and Peragallo).

The nominate variety of $C$. scutellum has always been reported to have more or less the same number of striae on both valves, always <13.5 in $10 \mu \mathrm{m}$ (Mizuno 1987, De Stefano et al. 2008, Table 1). At the infraspecific level, several taxa were described as having denser striae on the $\mathrm{RV}$ than on the SV, including C. scutellum var. parva sensu Okuno (1957), var. speciosa sensu Poulin et al. (1984), var. posidoniae, var. posidoniae f. decussata De Stefano and var. sullivanensis (De Stefano et al. 2000, 2008).

It can also be noted that the SV areola structure shared by several varieties is very different from that of C. scutellum var. scutellum. In var. baldjikiana, the hymen has a foramen in its centre (De Stefano et al. 2008), whereas in var. posidoniae and var. parva, the hymen has a rota (Riaux-Gobin and Romero 2003, pl. 30, De Stefano et al. 2008). The hymen has a complex volate cribrum in var. sullivanensis (De Stefano et al. 2008). Finally var. ornata has hymenes with a diamond-shaped rota-like structure (Mizuno 1982, Riaux-Gobin et al. 2011b). It can be noted that the internal view of the areolae in C. scutellum var. posidoniae (De Stefano et al. 2008, figure 110) is very close to that observed in var. ornata as illustrated in Riaux-Gobin et al. (2011b, pl. 68, figure 7). The valvocopula structure also shows some differences within the varieties of $C$. scutellum, with var. posidoniae showing fused fimbriae on the RV valvocopula, whereas in var. gorensis, the fimbriae are long and fused with the SV valvocopula.

A last characteristic concerns the submarginal internal hyaline rim of the RV, always present in the C. scutellum complex (De Stefano et al. 2008), except for var. parva whose RV valvocopula fimbriae lack papillae (De Stefano et al. 2008). Cocconeis scutellum var. parva has been described with very different appearances (cf., Suzuki et al. 2005), especially concerning the stria density on both valves (De Stefano et al. 2008, table 2); it is obviously a heterogeneous taxon that probably includes several different small-sized entities.

As previously noted, it is difficult to classify several taxa as varieties within $C$. scutellum or to argue for them to be described as new species. Nevertheless, $C$. spinachristi demonstrates enough unique features to be considered as a new species. Furthermore, as the identification and discrimination of the numerous varieties assigned to C. scutellum (14 valid taxa listed in VanLandingham 1968) mostly requires the use of the SEM, taxa studied only with LMs have probably been erroneously assigned to C. scutellum var. scutellum in the past (Mizuno 1987).

\section{Distribution and habitat of Cocconeis scutellum and allied taxa}

Among Cocconeis having fimbriate valvocopulae on both valves, C. scutellum is a geographically widespread taxon present in benthic communities from freshwater through brackish to marine environments (Mizuno 1987, De Stefano et al. 2008, table 1). Mainly described as epiphytic, 
C. scutellum is a cosmopolitan taxon also recorded occasionally from plankton (e.g., Burić et al. 2004). It can also be noted that several taxa, such as $C$. scutellum var. gorensis and var. clinoraphis, C. sagaraensis, C. alucitae and $C$. spina-christi, which share some similarities with C. scutellum, have a geographical distribution restricted to subtropical and tropical zones, whereas $C$. scutellum var. sullivanensis is restricted to temperate regions and might be considered as endemic to the southern Tyrrhenian Sea (De Stefano et al. 2008).

\section{Conclusions}

Only features observed with electron microscopy can be used to describe taxa pertaining to the Cocconeis scutellum lineage and allied taxa and to split them into different entities. The valvocopula of each valve has to be described in detail as these particular cingular bands bear important taxonomic features that are species-specific (Holmes et al. 1982).

Taking into account the large morphological diversity of the numerous valid varieties, a re-definition of $C$. scutellum was proposed by De Stefano et al. (2008), but all these taxa were finally split into four very different lineages based on the shape and structure of the poroid areolae on the SV and the fimbriae on the valvocopula(e).

Based on its unique valvocopula system, and particularly the anchor between the valvocopulae, which probably provides greater stability to the frustule, C. spinachristi is proposed as a new specie, in view of its remarkable characteristics, mainly its valvocopula system. The dense RV striation in the new taxon, never recorded in any C. scutellum variety, also differentiates it from other entities.

Acknowledgments: We acknowledge Dimitri Gorand (C2M, UPVD, F-Perpignan) and Elisabeth Sellier (CREMEM-Université Bordeaux I) for assistance with the SEM. We thank the USR 3278 (CNRS-EPHE) for funding diatom studies at Moorea Island and the CRIOBE-Moorea Team for valuable help in the field, particularly Franck Lerouvreur. Many thanks are also due to Pierre Compère (National Botanic Garden, Meise, Belgium) for revision of the Latin diagnosis and recommendation for the specific epithet spina-christi in place of antechristi. We wish to thank two anonymous reviewers for their helpful comments and Michel Poulin for his remarks and English improvement.

Received 29 May, 2012; accepted 28 June, 2013

\section{References}

Anonymous. 1975. Proposals for a standardization of diatom terminology and diagnoses. Nova Hedwigia, Beih. 53: 323-354.

Burić, Z., K. Caput and D. Viličič. 2004. Distribution of the diatom Cocconeis scutellum in the karstic estuary (Zrmanja, eastern Adriatic Sea). Biologia, Bratislava 59: 1-7.

De Stefano, M. and L. De Stefano. 2005. Nanostructures in diatom frustules: functional morphology of valvocopulae in Cocconeidacean monoraphid taxa. J. Nanosci. Nanotech. 5: 15-24.

De Stefano, M. and D. Marino. 2003. Morphology and taxonomy of Amphicocconeis gen. nov. (Achnanthales, Bacillariophyceae, Bacillariophyta) with consideration on its relationship with other monoraphid diatom genera. Eur. J. Phycol. 38: 361-370.

De Stefano, M. and O. Romero. 2005. A survey of alveolate species of the diatom genus Cocconeis (Ehr.) with remarks on the new section Alveolatae. Bibl. Diatomol. 52: 1-133.

De Stefano, M., D. Marino and L. Mazzella. 2000. Marine taxa of Cocconeis on leaves of Posidonia oceanica, including a new species and two new varieties. Eur. J. Phycol. 35: 225-242.

De Stefano, M., W.H.C.F. Kooistra and D. Marino. 2003. Morphology of the diatom genus Campyloneis (Bacillariophyceae, Bacillariophyta), with a description of Campyloneis juliae sp. nov. and an evaluation of the function of the valvocopulae. J. Phycol. 39: 735-753.
De Stefano, M., O.E. Romero and C. Tutti. 2008. A comparative study of Cocconeis scutellum Ehrenberg and its varieties (Bacillariophyta). Bot. Mar. 51: 506-536.

Ehrenberg, C.G. 1838. Die Infusionsthierchen als vollkommene Organismen. Ein Blick in das tiefere organische Leben der Natur. Verlag von Leopold Voss, Leipzig. pp. 548, pls 64.

Faissole, F. 1988. Hydrogéologie, paléohydrogéologie et diagénèse d'un système aquifère carbonaté récifal côtier. Temae (île de Moorea - Polynésie française). PhD Thesis, Université Bordeaux III, Bordeaux. pp. 269.

Hamm, C.E., R. Merkel, O. Springer, P. Jurkojc, C. Maler, K. Prechtel and V. Smetacek. 2003. Architecture and material properties of diatom shells provided effective mechanical protection. Nature 421: 841-843.

Holmes R.W., R.M. Crawford and F.E. Round. 1982. Variability in the structure of the genus Cocconeis Ehr. (Bacillariophyta) with special reference to the cingulum. Phycologia 21: 370-381.

Hustedt, F. 1931-1959. Die Kieselalgen Deutschlands, Österreichs und der Schweiz unter Berücksichtigung der übrigen Länder Europas sowie der angrenzenden Meeresgebiete. In: (L. Rabenhorst, ed) 2. Teil. - Kryptogamen-Flora von Deutschland, Österreich und der Schweiz. Band 7, Teil 2. Akademische Verlagsesellschaft, Leipzig. pp. 845. 
Kobayasi, H. and T. Nagumo. 1985. Observations on the valve structure of marine species of the diatom genus Cocconeis Ehr. Hydrobiologia 127: 97-103.

Lange-Bertalot, H. and K. Krammer. 1989. Achnanthes, eine Monographie der Gattung: mit Definition der Gattung Cocconeis und Nachträgen zu den Naviculaceae. Bibl. Diatomol. 18: 1-393.

McNeil, J., F.R. Barrie, H.M. Burdet, V. Demoulin, D.L. Hawksworth, K. Marhold, D.H. Nicolson, J. Prado, P.C. Silva, J.E. Skog, J.H. Wiersma and N.J. Turland. 2006. International code of botanical nomenclature. Regnum Vegetabile 146: 1-568.

Mizuno, M. 1982. Change in striation density and systematics of Cocconeis scutellum var. ornata (Bacillariophyceae). J. Plant Res. 95: 349-357.

Mizuno, M. 1987. Morphological variation of the attached diatom Cocconeis scutellum var. scutellum (Bacillariophyceae). J. Phycol. 23: 591-597.

Okuno, H. 1957. Electron-microscopical study of the fine structure of diatom frustules. XVI. Bot. Mag. 70: 216-222.

Poulin, M., L. Bérard-Therriault and A. Cardinal. 1984. Les diatomées benthiques de substrats durs des eaux marines et saumâtres du Québec. 1. Cocconeioideae (Achnanthales. Achnanthaceae). Naturaliste can. 111: 45-61.

Riaux-Gobin, C. and P. Compère. 2008. New Cocconeis taxa (Bacillariophyceae) from coral sands off Réunion Island (Western Indian Ocean). Diatom Res. 23: 129-146.

Riaux-Gobin, C. and O. Romero. 2003. Marine Cocconeis Ehrenberg (Bacillariophyceae) species and related taxa from Kerguelen's Land (Austral Ocean, Indian sector). Bibl. Diatomol. 47: 1-189.
Riaux-Gobin, C., P. Compère and A.Y. Al-Handal. 2011a. New Amphicocconeis species off Mascarenes and related taxa (Western Indian Ocean). Diatom Res. 26: 175-188.

Riaux-Gobin, C., O. Romero, P. Compère and A.Y. Al-Handal. 2011b. Small-sized Achnanthales (Bacillariophyta) from coral sands off Mascarenes (Western Indian Ocean). Bibl. Diatomol. 57: 1-234.

Ross, R., E.J. Cox, N.I. Karayeva, D.G. Mann, T.B.B. Paddock, R. Simonsen and P.A. Sims. 1979. An amended terminology for the siliceous components of the diatom cell. Nova Hedwigia, Beih. 64: 513-533.

Round, F.E., R.M. Crawford and D.G. Mann.1990. The diatoms. Biology and morphology of the genera. Cambridge University Press, Cambridge. pp. 747.

Suzuki, H. and J. Tanaka. 2006. A new diatom Cocconeis nagumoi Hid. Suzuki (Bacillariophyceae) from Japan. J. Jpn. Bot. 81: 282-288.

Suzuki, H., T. Nagumo and J. Tanaka. 2001. A new marine diatom, Cocconeis shikinensis sp. nov. (Bacillariophyceae) from Japan. Phycol. Res. 49: 137-144.

Suzuki, H., T. Nagumo and J. Tanaka. 2005. A new marine diatom Cocconeis sagaraensis Hid. Suzuki (Bacillariophyceae) from Japan. J. Jpn. Bot. 80: 176-185.

Townley, H.E. 2011. Diatom frustules: physical, optical, and biotechnological applications. In: (J. Seckbach and J.P. Kociolek, eds.) The diatom world, cellular origin, life in extreme habitats and astrobiology Vol. 19. Springer, Dordrecht. pp. 273-289.

VanLandingham, S.L. 1968. Catalogue of the fossil and recent genera and species of diatoms and their synonyms. Part II. Bacteriastrum through Coscinodiscus. Verlag J. Cramer, Lehre. pp. 494-1086. 
Copyright of Botanica Marina is the property of De Gruyter and its content may not be copied or emailed to multiple sites or posted to a listserv without the copyright holder's express written permission. However, users may print, download, or email articles for individual use. 